\title{
A Comparative Clinical Study on Tikshnavirechana Karma of Snuhiksheera Bhavit Katuki Churna and Icchabhedi Rasa W.S.R to Krura Koshthi Individuals
}

\author{
${ }^{1}$ Dr. Kanoongo Mayura , ${ }^{2}$ Dr. Patil Dinesh,${ }^{3}$ Dr. Kawthekar Prachi , ${ }^{4}$ Dr. Shrivastava Akhilesh \\ ${ }^{1}$ PG Scholar, Department of PanchaKarma, Shubhdeep Ayurved Medical College, Indore, M.P. \\ ${ }^{2}$ Assistant Professor, Department of PanchaKarma, Shubhdeep Ayurved Medical College, Indore, M.P. \\ ${ }^{3}$ Ayurveda Specialist at Ashtang Ayurveda College, Indore, M.P \\ ${ }^{4}$ Professor, Department of Rasa Shastra \& Bhaishjya Kalpana, Shubhdeep Ayurved Medical College, \\ Indore, M.P. \\ Correspondance Address: Dr. Kanoongo Mayura \\ PG Scholar, Department of PanchaKarma, Shubhdeep Ayurved Medical College, Indore, M.P.
}

\begin{abstract}
Virechana is a common panchakarma procedure where purgation is induced by drugs to eliminate morbid pitta dosha to maintain state of health within the body. Among various Virechaka drugs mentioned, Snuhi ksheera is considered best for Tikshna Virechana. But Jayapal is widely used in practice.

This study was conducted to compares the effect of Snuhiksheera Bhavit Katuki Churna and Jayapal (Icchabhedi Rasa) in Tikshna Virechana Karma in Krura Koshthi individuals. We compared both drugs on subjective and objective criteria. Among subjective criteria we have taken Samyak Shuddhi Lakshana of Virechana and we have developed some objective criteria to assess Shuddhi through Virechana Karma.

In this study total 60 patients were registered and divided into 2 groups. They were administered Snuhiksheera bhavit katuki churna and Icchabhedi Rasa. The result of study was critically analyzed on statistical basis in gaining symptoms of Samyak Shuddhi Lakshana i.e. Strotovishuddhi, Laghuta, Urja Agni, Praptishchavita Pitta Kaphanilanam, ManashchaTushti. And other Lakshana i.e. Vaigiki, weight, initiation of Vega, time between Vega, associated complaints, defecation on next day.

After applying proper statistical tools following result were obtained. The overall effect of therapy in Group A showed that maximum number of volunteers (53.4\%) had PravarShuddhi with discomfort, while 46.6\% volunteers had PravarShuddhi without discomfort.

The overall effect of therapy in Group B showed that maximum number of volunteers (76.6\%) had PravarShuddhi without discomfort, while $23.4 \%$ volunteers had PravarShuddhi with discomfort; none patient had Madhyam Shuddhi without discomfort or Heena Shuddhi in both groups.
\end{abstract}

Keywords -Tikshna Virechana, Snuhi Ksheera, Icchabhedi Rasa, Panchakarma, Krura Koshtha.

\section{INTRODUCTION}

Ayurveda plays an important role in curing disharmonies caused due to lifestyle changes. Virechana is well acceptable, easily tolerable and equally effective. The process of eliminating vitiated Doshas (Mala) through Adhomarga (Guda) is known as Virechana ${ }^{l}$. The Virechana therapy is medicated purification therapy that cleanses body from excess Pitta accumulation, morbid Pitta Dosha, Kapha Dosha accumulated at 
Dr. Kanoongo Mayura , International Journal of Ayurvedic \& Herbal Medicine 9(3) May.-June.2019 (3553-3560)

Pittasthana and Pitta samsargaja Doshas ${ }^{2}$ and also for vitiated Vata Dosha ${ }^{3}$. It is classified in 3 types as Mridu, Madhyam, and Tikshna Virechana.

Amongst the above three, Tikshna Virechana is helpful in Pravar Shuddhi especially in Krura Koshtha patient having enough strength ${ }^{4}$. These drugs cause numerous (Mahavega) motions and eliminate the Doshas in large quantity by quick(Kshipra) and gentle (Sukha) purgation without causing either much dizziness (Glani) or pain in heart area or anus or harmful to internal organs. ${ }^{5}$

Koshtha is a unique concept in Ayurveda. It is defined as nature of digestive tract, which represents motility of the intestines and movement of food and fecal matter of the stool. According to Ayurveda, Koshtha is divided into three categories - Krura, Madhyam and Mridu Koshtha. In Krura Koshtha Vata is more dominant in alimentary $\mathrm{canal}^{6}$, which reduces liquid content in the stool and resulting in elimination of hard stools.

Acharya Charaka mentioned different Virechana drugs, amongst them Snuhiksheera is considered best for TikshnaVirechana ${ }^{7}$. However, Jayapal is widely used in practice for Tikshna Virechana. Taking this into account it was thought that Snuhiksheera Bhavit Katutki Churna can offer better results with low doses too. This study was planned to compare the two drugs for knowing which would provide better result in Tikshna Virechana. To compare the results clinically patients with Krura Koshtha requiring Shodhana were selected as it is mandatory to treat diseases due to lifestyle changes.

\section{Aims and objectives:}

1. To evaluate the effect of Snuhiksheera Bhavit Katuki Churna in KruraKoshtha.

2. To study the effect of Ichhabhedi Rasa in KruraKoshtha.

3. To compare the effect of Snuhiksheera Bhavit Katuki Churna and Icchabhedi Rasa in KruraKoshtha.

\section{MATERIAL AND METHODS}

Total 60 Virechanarha volunteers having Krura Koshtha were selected irrespective of sex, religion, education, occupation, economic status etc. were selected from the O.P.D and I.P.D of Shubhdeep Ayurveda Medical College and Hospital (P.G institute), Indore (M.P).

\section{Inclusion criteria:}

1. Healthy volunteers having Krura Koshtha ${ }^{8}$.

2. Virechana Yogya ${ }^{9}$ volunteers having Krura Koshtha.

3. Age group between $16 \mathrm{yr}$ to $60 \mathrm{yr}^{10}$.

\section{Exclusion criteria:}

1. Age group below $16 \mathrm{yr}$ and above $60 \mathrm{yr}$.

2. Virechana Ayogya volunteers ${ }^{11}$.

3. Volunteers with Mridu to Madhyam Koshtha.

4. Patients with Alpa Bala and Alpa Dosha Dushti.

5. Patients with Asadhya Rogavastha.

Preparation of Snuhiksheera Bhavit Katuki Churna: On the basis of previous work done on this Yoga we had adapted this procedure ${ }^{12}$. Snuhiksheera was collected from nearby herbal garden in Sharad Ritu and Shodhana was done with Chincha Swarasa to remove its toxic effects. Then a single Bhawana of Snuhiksheera was given to Katuki Churna followed by drying in shadow. This preparation was used in this study for Virechana Karma in group A.

IcchabhediRasa: It was used as mentioned in BhaisjyaRatnavali -40/ 61-62 (Udararogadhikara) for Virechana in group B. 
Dr. Kanoongo Mayura , International Journal of Ayurvedic \& Herbal Medicine 9(3) May.-June.2019 (3553-3560)

Procedure: -Virechana Karma Vidhi.

Volunteers were selected randomly and divided in two groups having 30 volunteers each. Before treatment written consent was taken from volunteers.

\section{Purvakarma:}

1. Amapachana- Before starting Snehpana, Sunthi Churna $3 \mathrm{gm}$ bd with warm water after meals till Ama Pachana Lakshanas ${ }^{13}$ appear in both groups.

2. Snehapana- It was administered in both groups with Shudhha GoGhrita mixed with a pinch of Saindhava Lavana for 3-7 days in increasing order or until Samyaka Snighda Lakshana ${ }^{14}$ appears (whichever achieved first).

3. Abhyanga \& Swedana- Abhyanga with Murchhit Tila Taila and Sarvang Vashpa Swedana with Dashmoola Kwatha was given for 3 days prior to Virechana in both groups.

$>$ Patient was advised to take Laghu, Ushna diet that does not cause aggravation of Kapha during the Vishrama Kala (i.e three days gap period).

\section{Pradhana Karma:}

$>$ Then patient was instructed to take Virechaka Yoga with Anupana after Kaphakala is passed (i.e. between 9am -10 am) and then wait until Virechana Vega start.

> Group A: 30 randomly selected volunteers were given Snuhiksheera Bhavit Katuki Churna (3-5 gm with Draksha Kwatha $100 \mathrm{ml}$ ) as Virechaka Yoga

> Group B: 30 randomly selected volunteers were given Icchabhedi Rasa (dose-250mg to 500mg with Draksha Kwatha $100 \mathrm{ml}$ ) as Virechaka Yoga.

$>$ After commencement of Vega proper monitoring was done and patient was advised to take Draksha Kwatha after every Vega to initiate them without discomfort.

$>$ Thereafter, when Virechana stopped, patient was advised to take rest and instructed to follow behavioral and dietetic regimens.

\section{Paschat Karma:}

Samsarjana Karma was performed according to type of Virechana Karma Shuddhi. Patient was given detailed instruction about the diet to be followed i.e. Peya, Vilepi, Akrut Yusha/ Mamsarasa and Krut Yushal Mamsarasa.

\section{Timelines:}

Total study period: Till the enrolment of required number of patients.

Treatment period: 18 days

Follow up period: 1 month

\section{Assessment criteria}

Table No. 1 - Showing Scoring Pattern Of Subjective And Objective Criteria

\begin{tabular}{|c|c|c|c|c|}
\hline $\begin{array}{l}\text { Scoring } \\
\text { Criteria }\end{array}$ & $\mathbf{0}$ & 1 & 2 & 3 \\
\hline Stotovishuddhi & $\begin{array}{lr}\begin{array}{l}\text { Feeling } \\
\text { constipation } \\
\text { Virechana }\end{array} & \text { after } \\
\end{array}$ & $\begin{array}{lr}\text { Feeling } & \text { of } \\
\text { distension } & \text { after } \\
\text { Virechana. } & \\
\end{array}$ & $\begin{array}{l}\text { No feeling of } \\
\text { satisfaction after } \\
\text { Virechana }\end{array}$ & $\begin{array}{lr}\text { Feeling of } & \text { Koshtha } \\
\text { Laghava } & \text { after } \\
\text { Virechana } & \\
\end{array}$ \\
\hline Laghuta & $\begin{array}{l}\text { Feeling of Guruta } \\
\text { with discomfort } \\
\text { after Virechana }\end{array}$ & $\begin{array}{l}\text { Feeling of Guruta } \\
\text { without } \\
\text { discomfort after } \\
\text { Virechana }\end{array}$ & $\begin{array}{l}\text { Feeling of Laghuta } \\
\text { but can't perform } \\
\text { routine work }\end{array}$ & Feeling of Laghuta \\
\hline Urja agni & $\begin{array}{lr}\text { No feeling } & \text { of } \\
\text { hunger } & \text { after } \\
\text { Virechana } & \text { upto } \\
\text { night. } & \\
\end{array}$ & 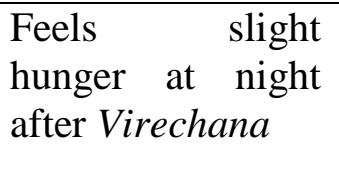 & $\begin{array}{l}\text { Feels slight hunger } \\
\text { just after Virechana }\end{array}$ & $\begin{array}{l}\text { Feeling extreme } \\
\text { hunger just after } \\
\text { Virechana }\end{array}$ \\
\hline
\end{tabular}


Dr. Kanoongo Mayura , International Journal of Ayurvedic \& Herbal Medicine 9(3) May.-June.2019 (3553-3560)

\begin{tabular}{|c|c|c|c|c|}
\hline $\begin{array}{l}\text { Praptisch } \\
\text { vitapittakapha } \\
\text { anilanam }\end{array}$ & Not observed & $\begin{array}{l}\text { Pitta observed but } \\
\text { not Kapha }\end{array}$ & Kapha observed. & $\begin{array}{l}\text { All Lakshana } \\
\text { Observed. }\end{array}$ \\
\hline Mansch tushti & $\begin{array}{l}\text { No feeling of well } \\
\text { being }\end{array}$ & $\begin{array}{l}\text { Feeling of well- } \\
\text { being next day. }\end{array}$ & $\begin{array}{l}\text { Feeling of well- } \\
\text { being at night. }\end{array}$ & $\begin{array}{l}\text { Feeling of well- } \\
\text { being just after last } \\
\text { Vega. }\end{array}$ \\
\hline Initiation of vega & $>3 \mathrm{hr}$. & 2- $3 \mathrm{hr}$. & $1-2 \mathrm{hr}$. & $<1 \mathrm{hr}$. \\
\hline $\begin{array}{l}\text { Time between } \\
\text { vega }\end{array}$ & $>30 \mathrm{~min}$ & $15-30 \mathrm{~min}$ & $10-15 \mathrm{~min}$ & $1-9$ min. \\
\hline $\begin{array}{l}\text { Associated } \\
\text { complaints }\end{array}$ & $\begin{array}{lr}>3 & \text { Lakshana } \\
\text { observed during } \\
\text { every Vega. }\end{array}$ & $\begin{array}{l}2-3 \quad \text { Lakshana } \\
\text { observed during } \\
\text { every Vega. }\end{array}$ & $\begin{array}{lr}1-2 & \text { Lakshana } \\
\text { observed } & \text { during } \\
\text { every Vegar } & \end{array}$ & $\begin{array}{lr}-1 & \text { Lakshana } \\
\text { observed } & \text { during } \\
\text { every Vega } & \\
\end{array}$ \\
\hline $\begin{array}{l}\text { Defecation } \\
\text { next day }\end{array}$ & $\begin{array}{l}\text { Not passed } \\
\text { feeling constipated. }\end{array}$ & After 2 pm & Between 12- 2 pm & $\begin{array}{l}\text { Normal next day } \\
\text { before } 12: 00 \text { noon. }\end{array}$ \\
\hline
\end{tabular}

\section{OBSERVATION}

Table No. 2 - Showing Observation Of Virechana Karma

\begin{tabular}{|l|l|l|}
\hline Average dose of Virechana Yoga & Snuhiksheera bhavit kutaki churna(Group A) & $3.9 \mathrm{gm}$ \\
\cline { 2 - 3 } & IcchabhediRasa (Group B) & $358.3 \mathrm{mg}$ \\
\hline \multirow{2}{*}{$\begin{array}{l}\text { Average time taken for initiation } \\
\text { of Vega }\end{array}$} & Group A & $1.6 \mathrm{hr}$ \\
\cline { 2 - 3 } Average number of Vega & Group B & $2.17 \mathrm{hr}$ \\
\hline \multirow{2}{*}{ Kaphanata lakshana } & Group A & 15.2 \\
\cline { 2 - 3 } & Group B & 20.7 \\
\hline & Group A & $86.6 \%$ patients \\
\cline { 2 - 3 } & Group B & $96.6 \%$ patients \\
\hline
\end{tabular}

Table No.3 - Showing Observation Of Subjective And Objective Criteria

\begin{tabular}{|l|l|l|l|l|l|}
\hline Criteria & Maximum grade & Group A & Group B & Total & \% \\
\hline Srotovishuddhi & $\begin{array}{l}\text { Feeling of Koshtha Laghava } \\
\text { after Virechana }\end{array}$ & 19 & 23 & 42 & $70 \%$ \\
\hline Laghuta & Feeling of Laghuta & 14 & 24 & 38 & $63.4 \%$ \\
\hline Urja agni & $\begin{array}{l}\text { Feeling of extreme hunger just } \\
\text { after Virechana. }\end{array}$ & 15 & 23 & 38 & $63.4 \%$ \\
\hline $\begin{array}{l}\text { Praptishch } \\
\text { Vitapittakapha anilanam }\end{array}$ & All Lakshana Observed. & 12 & 20 & 32 & $53.33 \%$ \\
\hline ManschTusht & $\begin{array}{l}\text { Feeling of well- being just after } \\
\text { Virechana }\end{array}$ & 12 & 19 & 31 & $51.66 \%$ \\
\hline Vaigiki & $11-20$ & 18 & 13 & 31 & $51.6 \%$ \\
\hline Initiation of Vega & $<1$ hr. & 16 & 6 & 22 & $36.66 \%$ \\
\hline Time between Vega & $10-15$ min & 9 & 10 & 19 & $31.66 \%$ \\
\hline Defecation on next day & $\begin{array}{l}\text { Normal next day before 12:00 } \\
\text { noon. }\end{array}$ & 18 & 11 & $48.33 \%$ \\
\hline Associated complaints & $\begin{array}{l}\text {-1 Lakshana observed during } \\
\text { every Vega. }\end{array}$ & 16 & 24 & 40 & $66.66 \%$ \\
\hline Weight reduction & $0-2$ kg & 15 & 13 & 28 & $46.7 \%$ \\
\hline
\end{tabular}


Dr. Kanoongo Mayura , International Journal of Ayurvedic \& Herbal Medicine 9(3) May.-June.2019 (3553-3560)

\section{RESULTS AND DISCUSSION}

Table No.4 - Showing Overall Result Obtained In Both Groups.

\begin{tabular}{|l|l|l|l|l|l|l|l|}
\hline \multirow{2}{*}{ Criteria } & \multicolumn{4}{l}{ Group A } & \multicolumn{2}{l|}{ Group B } & \\
\cline { 2 - 8 } & Mean & S. D & S. E & Mean & S. D & S. E & p-value \\
\hline Srotasvishuddhi & 2.60 & 0.56 & 0.10 & 2.70 & 0.60 & 0.11 & $>0.01$ \\
\hline Laghuta & 2.23 & 0.40 & 0.16 & 2.8 & 0.85 & 0.07 & $<0.01$ \\
\hline Urjaagni & 2.77 & 0.75 & 0.14 & 2.30 & 0.43 & 0.08 & $<0.01$ \\
\hline PraptishchaVitapittakapahanilanam & 2.23 & 0.73 & 0.13 & 2.67 & 0.48 & 0.09 & $<0.01$ \\
\hline Manshchtushti & 2 & 0.98 & 0.18 & 2.57 & 0.63 & 0.11 & $<0.01$ \\
\hline Vaigiki & 15.5 & 5.07 & 0.93 & 20.77 & 4.48 & 0.82 & $<0.001$ \\
\hline Initiation of Vega & 1.83 & 0.87 & 0.16 & 2.4 & 0.72 & 0.13 & $<0.01$ \\
\hline Time between Vega (min) & 1.43 & 1.01 & 0.18 & 2.1 & 0.88 & 0.16 & $<0.01$ \\
\hline Defecation on next day & 2.43 & 0.82 & 0.15 & 1.67 & 1.21 & 0.22 & $<0.01$ \\
\hline Associated symptoms & 2.27 & 0.98 & 0.18 & 2.8 & 0.41 & 0.07 & $<0.01$ \\
\hline Weight reduction(kgs) & 2.67 & 1.21 & 0.22 & 3.13 & 1.17 & 0.21 & $>0.01$ \\
\hline
\end{tabular}

Interpretation - mean score (x), standard deviation (S.D), standard error (S.E). The result was interpreted as

$\checkmark \quad \mathrm{P}>0.05$ - insignificant improvement

$\checkmark \quad \mathrm{P}<0.05$ and $\mathrm{P}<0.01$ - significant improvement

$\checkmark \quad \mathrm{P}<0.001$ - highly significant improvement

Table no. 5 - Total Effect of Therapy

\begin{tabular}{|l|l|l|l|l|}
\hline \multirow{2}{*}{ Effect } & Group A & Group B \\
\cline { 2 - 5 } & No. of patients & Percentage & No. of patients & Percentage \\
\hline Heena Shuddhi & 0 & $0 \%$ & 0 & $0 \%$ \\
\hline Madhyam Shuddhi without discomfort & 0 & $0 \%$ & 0 & $0 \%$ \\
\hline Pravar Shuddhi with discomfort & 16 & $53.4 \%$ & 7 & $23.4 \%$ \\
\hline Pravar Shuddhi without discomfort & 14 & $46.6 \%$ & 23 & $76.6 \%$ \\
\hline
\end{tabular}

Total effect of therapy: In group A: The overall effect of therapy showed that maximum number of patients (53.4\%) had Pravar Shuddhi with discomfort, while 46.6\% patients had Pravar Shuddhi without discomfort,. In group B: The overall effect of therapy showed that maximum number of patients (76.6\%) had Pravar Shuddhi without discomfort, while $23.4 \%$ patients had Pravar Shuddhi with discomfort, none patient had Madhyam Shuddhi without discomfort or Heena Shuddhi in both groups.

\section{Discussion on Subjective Criteria}

Srotovishudhi: Srotovishuddhi is achieved when Vikruta Pitta, Kapha, Mala etc. which are causing Marga Avarodha is expelled out through Virechana hence Vyadhi Shamana occurs. All Srotas may have this type of Avarodha, though Avarodha of any Srotos can be removed by Virechana however; Avarodha of Purishvaha, Annavaha and Rasavaha is especially removed by Virechana.

Laghuta: After Samyaka Virechana person feels Laghutvam because Vikruta Dosha, Dushya and Ama etc. are eliminated. For every $500 \mathrm{ml}$ of fluid elimination, one pound of weight will be decreased. Hence person feels lightness in the body.

Urja Agni: After Samyaka Virechana Agni will be little bit increased as all the Dosha and fluid contents are eliminated, hence the person feels Kshudha and Trishna

Praptishch Vitapittakapha anilanam: There should be sequential elimination of Mala, Pitta, Kapha and Vayu. Virechana is aimed to eliminate the morbid Pitta from the body which is present in the 
Dr. Kanoongo Mayura , International Journal of Ayurvedic \& Herbal Medicine 9(3) May.-June.2019 (3553-3560)

Adhoamashaya. After complete Pitta is eliminated, it is the turn of Kapha to come out which is present in Amashaya. So, presence of Kapha at the end indicates the completion of process. This is a sign of Samyak Virechana.

ManschTushti: Elimination of morbid factors from the body person feels Prassanta of Manas. Indriyas become capable of perceiving their senses.

\section{Discussion on Objective Criteria}

Vaigiki: Both the drugs used in the study were Tikshna Virechaka and capable of producing Pravara Vega. But due to use of drugs in lesser dose more volunteers showed Madhyama Vega.

Initiation of Vega: Virechana drugs acts after attaining Pakva Awastha. The commencement of Vega depends on digestion of Virechaka Yoga. Thus, initiation of Vega took place 1- 2 hour in maximum volunteers as this much time is required for digestion.

Time between Vega: Good Virachaka drug should have minimum time between Vegas for proper elimination.

Defecation on Next day: Within 24 hrs patient's bowel habits should be normal. If patient is constipated this shows Vata Prakopa.

Associated Complaints : Study was conducted by Tikshna Virechana Yoga some patients had complaint of nausea, abdominal cramp, etc but maximum volunteers showed least associated complaint this may be due to use of Virechanopaga Kwatha after every Vega, which increases palatability and eases the process of Tikshna Virechana.

Weight reduction: Virechana not only reduces the fluid content in the body but it definitely improves BMR thus resulting in weight reduction. During the follow-up it was observed that reduced weight was not increased even after $2-3$ months.

\section{Probable Mode of action of Virechaka yoga:}

Icchabhedi Rasa:

It is the most widely used drug for Tikshna Virechana. It acts as pacifier of Vata and Kapha. It can produce much Virechana Vega even in low doses too. Its main ingredient is Jayapal which is mentioned as Virechaka drug in Charak Kalpasathana. Ingredients of Icchabhedi Rasa have Tikshna, Ushna, Yogavahi properties. Jayapal due to its Tikshna guna breaks the Doshasanghata and removes Strotorodha. Ushnaguna pacifies Vata and Kapha dosha and also aids in dissolution of Dosha. Parada and Gandhaka due to their Yogavahi action spread the drug in whole body within short time and it reaches to minute channels of the body and eradicates the accumulation of Doshas. It spreads in the whole body due to its infiltrative property.Tankan present in Icchabhedi Rasa has Kshariya property which helps in increasing Dravatvain Pakwashaya and easy removal of morbid Doshas. Maricha and Shunthi acts as Agnideepak.

\section{Snuhiksheera Bhavit Katuki Churna:}

Among all Virechana Dravyas Snuhi is designated as Tikshnatama i.e. drastic purgative. It alleviates the Kapha and VataDosha. It has Tikshna Rechana property thus produces numerous Vega without much effort and expels Dosha in liquefied form in large amount. Due to its Ushna and Tikshna Guna it aids in cleaning of Srotorodha and removes congestion from the body. Snigdha Guna restricts Vataprakopa. It easily destroys the accumulation of Doshas and helps in easy removal of Dosha from the body if used in proper manner. On the other hand, Katuki has Bhedana action on Doshas i.e.it brings them out by breaking Doshasanghata of Shakagata as well as Koshthagata Doshas. It has TiktaRasa which allievates Kapha Dosha and it also has Deepana property. Katuki, when combined with SnuhiKsheera, due to their properties Dosha Pachana occurs and morbid Doshas are expelled which produces Dhatu Shodhana. 


\section{CONCLUSION:}

Pravar Shudhhi can be achieved in Krura Koshthi individuals only through proper use of Tikshna Virechana drugs. Snuhi ksheera Bhavit Katuki Churna and Icchabhedi Rasa both can produce Pravar Shuddhi, due to their Tikshna Virechana property. Though Snuhi ksheera Bhavit Katuki Churna is a Kashtha Aushadhi but it produces Vaigiki Shuddhi nearly similar to the Icchabhedi Rasa which is a Rasa Aushadhi. It can be used in conditions when Pravar Shuddhi is required but where use of Rasa Aushadhi has to be avoided. Initiation of Vega, less associated complaints and Defecation on next day was found better in Snuhi ksheera Bhavit Katuki Churna group, proving its rapid action and efficacy for Shodhana purpose. It produces less complications arising during Virechana procedure. It may produce much better result if given in increased dose and more number of Bhawana can also increase its potency.

Icchabhedi Rasa provides much better results in showing Samyak Virechana Lakshana. Laghuta, UrjaAgni, Praptishch vita pitta kapha anilanam, Mansch Tushti, Vaigiki, less Time between Vega were found better in Icchabhedi Rasa group, proves it as a good Tikshna Virechana drug though sometimes along with some complications like weakness, vomiting, Vataprakopa. It was observed in the study that when Virechanopaga Kwatha was administered after every Vega, accelerated the process of Virechana as well as it prevents Vataprakopa, Daha, and prevents weakness due to the process.

\section{REFERENCES}

1. Agnivesha; Charaka Samhita; edited by Satyanarayana Shastri; Chaukhambha Bharati Academy,Varanasi; reprint edition 2009; Kalpasthana, Chapter-1, verse - 4, p- 890.

2. Vagbhata: AshtangSamgraha with hindi commentary; Atrideva Gupta, Sutrasthana 27/5, Krishnadas Academy, Varanasi; part I, reprint 2002, p- 197.

3. Agnivesha; Charaka Samhita; edited by Satyanarayana Shastri; Chaukhambha Bharati Academy,Varanasi; reprint edition 2009; Chikitsasthana ,Chapter-28, verse - 83, p- 792.

4. Agnivesha; Charaka Samhita; edited by Satyanarayana Shastri; Chaukhambha Bharati Academy,Varanasi; reprint edition 2009; Kalpasthana, Chapter - 12, verse - 58, p- 947.

5. Agnivesha; Charaka Samhita; edited by Satyanarayana Shastri; Chaukhambha Bharati Academy,Varanasi; reprint edition 2009; Kalpasthana,Chapter - 12, verse -51,52, p- 946

6. Agnivesha; Charaka Samhita; edited by Satyanarayana Shastri; Chaukhambha Bharati Academy,Varanasi; reprint edition 2009; Sutrasthana, Chapter - 13, verse - 68, p- 273.

7. Agnivesha; Charaka Samhita; edited by Satyanarayana Shastri; Chaukhambha Bharati Academy,Varanasi; reprint edition 2009; Sutrasthana, Chapter-25, verse - 40, p-468

8. Susruta; Susruta Samhita; edited by Ambikadutta Shastri; 4.33.21; Chaukhambha Sanskrit Sansthan; reprint 2011; Chikitsasthana, Chapter -33, verse - 21, p-179.

9. Agnivesha; Charaka Samhita; edited by Satyanarayana Shastri; Chaukhambha Bharati Academy,Varanasi; reprint edition 2009; Siddhisthana, Chapter - 2, Verse -13, p- 981

10. Sharangdhara; Sharangdhara Samhita; edited by Shailaja Shrivastava; 1.6.18; Chaukhambha Orientalia, reprint edition 2009; Purvakhanda, Chapter -6, verse- 18, p- 54.

11. Agnivesha; Charaka Samhita; edited by Satyanarayana Shastri; Chaukhambha Bharati Academy,Varanasi; reprint edition 2009; Siddhisthana, Chapter - 2, Verse -11; p- 980

12. Dr. Pragna Shah; Role of Virechana with SnuhibhavitKatuki in the management of essential Hypertension; 2005

13. Vagbhata; AshtangHridayam; edited by Tripathi B.; Chaumkhambha Sanskrit Pratishthan ; Sutrasthana, Chapter-13, verse -23-24; p- 188.

14. Agnivesha; Charaka Samhita; edited by Satyanarayana Shastri; Chaukhambha Bharati Academy,Varanasi; reprint edition 2009; Sutrasthana, chapter -13,verse-58;p-271. 
Dr. Kanoongo Mayura , International Journal of Ayurvedic \& Herbal Medicine 9(3) May.-June.2019 (3553-3560) 